\title{
ANALISIS MAKNA LEKSIKAL PADA LIRIK LAGU KAMU DAN KENANGAN KARYA MAUDY AYUNDA
}

\author{
Afrida Yanti ${ }^{1}$, Putri Ardiani Lubis ${ }^{2}$, Novi Amelia Natasha ${ }^{3}$, Efraim Sitorus ${ }^{4}$, Frinawati \\ Lestarina Barus ${ }^{5}$ \\ Universitas Negeri Medan \\ Jurusan Bahasa dan Sastra Indonesia, FBS, Medan. \\ 1 afridayanti259@ gmail.com, ${ }^{2}$ putriardiani38@ gmail.com \\ 3tasyahutagalung2512@gmail.com ${ }^{4}$ efraimsitorus205@gmail.com \\ frinabarus@unimed.ac.id
}

\begin{abstract}
Abstrak
Penelitian ini berjudul analisis makna leksikal pada lagu "Kamu dan Kenangan" karya Maudy Ayunda Penelitian ini bertujuan untuk mendeskripsikan analisis makna leksikal pada sebuah lirik lagu. Adapun peneletian ini menggunakan metode deskriptif kualitatif data dimulai dari tahapan membaca dan mengetahui lirik lagu yang akan dianalisis agar dapat disimpulkan hasil dari penelitian mengenai makna leksikal yang terkandung dala lagu "Kamu dan Kenangan" karya Maudy Ayunda.
\end{abstract}

Kata Kunci: Bahasa, Semantik, Makna Leksik

\section{PENDAHULUAN}

Makna sering kita jumpai pada satu kata atau kalimat terkadang makna tersebut sering menimbulkan perbedaanterhadap pembaca bagaimana sebenarnya tafsiran dari makna tersebut. Bahasa memiliki sifat yang tidak kabur dalam makna yang terkandung di dalam nya karena pada dasarnya makna memiliki dasar yang memiliki realita pada setiap maknanya. Dapat kita lihat Pada setiap lirik lagu terdapat makna yang terkandung di dalamnya atau realita, perasaan, dan ide yang dituangkan oleh pengarang dalam bentuk lirik. Namun, pada umumnya makna memiliki beberapa jenis, yaitu menurut Pateda (2010: 97) beliau menjelaskan beberapa jenis makna yaitu makna efektif, makna denotatif, makna deskriptif, makna ekstensi, makna emotif, makna gramatikal, makna ideasional, makna intensi, makna khusus, makna kiasan, makna kognitif, makna kolokatif, makna konotatif, makna konseptual, makna konstruksi, makna kontekstual, makna referensial.

Lagu merupakan sebuah seni dalam bentuk nada ataupun suara yang dikombinasikan dengan irama dan diringi oleh alat musik sehingga dapat 
diperdengarkan oleh banyak orang. Lirik lagu merupakan istilah kata yang dituangkan dalam sebuah pengekspresian melalui pengarang tentang suatu hal yang telah dilihatnya. Untuk mengekspresikannya, pengarang harus dapat menciptakan sebuah lirik dengan makna yang terkandung di dalam setiap lirik baik yang tersirat maupun yang tersurat. Dengan lirik lagu para pendengar bisa merasakan bagian dari untaian setiap kata yang terdapat pada lirik lagu tersebut. Lirik lagu diciptakan melalui suatu proses dengan pemilihan diksi yang tepat sehingga mampu mengasilkan lirik yang baik. Lirik juga sebuah alunan nada dan bunyi yang indah dan memiliki makna yang mendalam untuk didengarkan oleh masyarakat terutama dikalangan Remaja. Hal ini bisa dikarenakan lirik pada sebuah lagu memiliki daya tarik dari segi bahasa dan susunan kalimat.

Oleh sebab itu, dalam lirik lagu terdapat sebuah makna kata yang terlukiskan. Hal ini yang menjadi alasan mengapa lirik lagu menjadi subjek yang ingin diteliti. Lirik lagu pada penelitian ini diperoleh pada lirik lagu "Kamu dan Kenangan karya Maudy Ayunda" dan lirik lagu ini akan dijadikan objek penelitian yang terkait dengan makna leksikal. Lagu "Kamu dan Kenangan" Karya Maudy Ayunda merupakan salah satu yang dinyanyikan oleh Maudy Ayunda yang lagu ini juga menjadi soundrack film Habibie dan Ainun. Lagu ini memiliki genre musik yang bernuansa megah dengan balutan strings yang dirangkai sangat indah dalam setiap lirik nya dan bermakna sangat dalam. Proses penelitian dilakukan dalam bentuk analisis makna leksikal pada lirik lagu "Kamu dan Kenangan" karya Maudy Ayunda.Lirik lagu pada penelitian ini diperoleh terdapat pada lirik lagu Kamu dan Kenangan Karya Maudy Ayunda, dan lirik ini akan saya jadikan sebagai objek penelitian saya yang terkait dengan makna leksikal pada lirik lagu.

\section{KAJIAN TEORI}

\section{A. Definisi Semantik}

Menurut Tarigan (1985 : 7) Semantik adalah suatu bidang yang mempelajari mengenai suatu makna yang memiliki hubungan makna dengan lainnya dan memiliki pengaruh terhadap manusia. Makna merupakan adanya tanda lingustik. Makna bahasa sering dijadikan perbincangan masyarakat khususnya pengguna bahasa. Makna sering ditemui dalam ranggkain kata dan kalimat. Makna yang terdapat pada kata atau kalimat terkadang sering membingungkan pembaca bagaimana sebenarnya 
tafsiran dari makna tersebut. Bahasa memiliki sifat kabur dalam makna yang terkandung di dalam bentuk pada dasarnya hanya mewakili realita. Pada setiap lirik lagu terdapat makna yang terkandung di dalamnya atau realita, perasaan, dan ide yang dituangkan oleh pengarang dalam bentuk lirik.

Berdasarkan makna leksikal yang dipilih untuk dijadikan sebagai penelitian. Makna leksikal merupakan bagian kecil dari kata yang mempunyai arti penuh. Makna ini sangat menarik untuk diteliti karena makna leksikal memiliki ragam unsur terdapat di dalam bahasa dan di luar bahasa. Makna leksikal juga dikatakan suatu makna yang sesuai dengan referennya. Misalnya leksem kuda di luar bahasa memiliki makna hewan berkaki empat yang dapat digunakan untuk membawa orang atau bisa dikendarain, sedangkan leksem kuda di dalam bahasa, yaitu binatang yang menyusui, berkuku satu, dan biasa dipelihara oleh manusia. Oleh karena itu, makna leksikal dijadikan alasan untuk dapat diteliti. Musik adalah sebuah curahan hati seseorang yang menulisnya. Musik tidak dapat dicetuskan melalui perantara seni lainnya, sehingga musik dikatakan tempat manusia untuk menuangkan segala yang timbul dari pikirannya.

\section{B. Makna Leksikal}

Menurut KBBI makna leksikal merupakan makna yang unsur bahasanya sebagai lambing benda atau peristiwa. Makna leksikal juga merupakan makna yang bersifat dasar, dan belum mengalami konotasu dan hubungan gramatik dengan kata lain (Aminunuddin 1988 : 87 ), Makna leksikal memiliki peran dalam kebahasaan sehingga makna leksikal meliputi repitisi (Pengulangan), Sinomini (padan kata), dan Anatonimi (Lawan Kata)

\section{a. Repetisi (Pengulangan)}

Menurut para ahli Oktafianus ( 2006 : 63) repetisi dikatakan munculnya bentuk yang sama untuk menjadi makna yang sama kedalam sebuah wacana. Sedangkan menurut para ahli Sumarlam $(2008 ; 43)$ repetisi merupakan pengulangan suatu lingual yang memberi tekanan untuk sebuah konteks yang sesuai. Pengulangan kata dapat berupa kata, frasa atau juga klausa. Repetisi adalah proses leksemik yang mengubah kata menjadi kata kompleks dengan cara penyebutannya (Kridalaksana dalam Sudaryat 2009 : 70) 


\section{b. Sinonimi (Padan Kata)}

Sinonimi merupakan sebuah istilah yang memiliki makna yang sama (Gorys Keraf, 2004 : 34). Berdasarkan wujud lingual yang sudah dipelajari, terdapat lima bagian lingual, (1) sinonim antara morfem bebas dan terikat (2) kata yang dihubungkan dengan kata (3) kata yang dihubungkan dengan frasa (4) frasa yang sesuai dengan frasa (5) klausa atau kalimat (Sumarlam, ed. 2008 : 39). Sinonimi berguna menjalin hubungan antara lingual satu dengan lingual lainnya dalam sebuah wacana yang memiliki pemakaian dua kata dalam dua klausa (Sumarlam 2003 : 39)

\section{c. Antonimi (Lawan Kata)}

Antonimi lawan kata merupakan sebuah makna yang bertentangan atau dapat dikatakan berbeda (Gorys Keraf, 2004 : 39). Anatonimi biasanya dapat disebut oposisi dengan makna berdasarkan sifatnya, seperti oposisi mutlak, kutub, hubungan, hirarkial dan majemuk. Makna leksikal merupakan sebuah kebahasaan yang memiliki sifat dasar, seperti bahasa yang belum terdapat konotasi dan tidak ada hubungannya gramtik dengan sebuah kata ( Aminunuddin 1988 : 87 ). Dari setiap pembahasan makna leksikal yang sudah dipaparkan dari para ahli bahkan beberapa orang lainnya,sehingga dapat disimpulkan bahwa makna leksikal disebut makna yang sebenarnya. Antonimi dapat diartikan sebagai makna yang berlawanan dengan lingual lainnya ( Sumarlam 2003 : 40)

Makna leksikal memiliki peran yang sangat penting bagi pengguna bahasa karena makna ini menghubungkan antara bahasa, kata, dan kalimat dalam bahasa bahkan luar bahasa. Makna leksikal di dalam bahasa merupakan makna yang memiliki arti penuh yang tidak dapat diubah kebenarannya atau sudah ada di dalam kamus, sedangkan makna leksikal di luar bahasa merupakan pemakna yang sesuai dengan tingkat pengalaman dari pengguna bahasa dalam menafsirkan suatu kata itu sendiri. Dengan demikian, untuk memahami suatu bentuk bahasa, kata, maupun kalimat diperlukan pemahaman mendalam khususnya mengenai makna leksikal. Makna leksikal adalah sebuah makna yang tertuju pada kata dasar atau kata asli yang belum mengalami afiksasi. Pengetahuan tersebut akan memudahkan pengguna bahasa untuk menafsirkan makna tersebut dapat dijumpai dalam kehidupan kita. Sehingga penelitian ini, lirik lagu menjadi contoh wujud dari bentuk 
makna yang sering dijumpai oleh penggunaan sebuah lingual.

\section{METODE PENELITIAN}

Penelitian ini menggunakan metode deskriptif. Tujuan dari penelitian ini yaitu guna mendeskripsikan bentuk pada satuan bahasa yang terdapat pada lirik lagu Maudy Ayunda yang berjudul "Kamu dan Kenangan". sumber data yang digunakan adalah data tertulis yang berupa lirik lagu "Kamu dan Kenangan" karya Mudy Ayunda. Penelitian ini mengambil data Primer dan Sekunder. Data Primer berupa makna leksikal yang terdapat pada lirik lagu "Kamu dan Kenangan" Karya Maudy Ayunda dan data sekunder berupa buku, jurnal penelitian dan dokumentasi yang membahas mengenai makna leksikal pada lirik lagu "Kamu dan Kenangan" buku yang menjadi acuan yang berisi teori makna leksikal dalam kajian semantik. Penelitian ini menggunakan teknik pengumpulan data dokumentasi melalui Youtube dimana dapat diunduh dalam melihat lirik lagu yang ingin dikaji yaitu lirik lagu "Kamu dan Kenangan" Karya Maudy Ayunda juga denan metode baca dan catat.

\section{HASIL DAN PEMBAHASAN}

\section{A. Analisis Makna Leksikal}

Lirik lagu Kamu dan Kenangan Karya Maudy Ayunda

(1) Seusai itu senja jadi sendu awan pun mengabu

(2) Kepergianmu menyisakan duka dalam hidupku

(3) 'Ku memintal rindu menyesali waktu mengapa dahulu

(4) Tak kuucapkan aku mencintaimu sejuta kali sehari

(5) Walau masih bisa senyum

(6) Namun tak selepas dulu

(7) Kini aku kesepian

(8) Kamu dan segala kenangan

(9) Menyatu dalam waktu yang berjalan

(10) Dan aku kini sendirian

(11) Menatap dirimu hanya bayangan

(12) Tak ada yang lebih pedih

(13) Daripada kehilangan dirimu

(14) Cintaku tak mungkin beralih

(15) Sampai mati hanya cinta padamu (padamu)

(16) Ho-o-o-o-oh ...

(17) Walau masih bisa senyum

(18) Namun tak selepas dulu

(19) Kini aku kesepian

(20) Kamu dan segala kenangan (kenangan)

(21) Menyatu dalam waktu yang 
berjalan (berjalan)

(22) Dan aku kini sendirian

(23) Menatap...

\section{Hasil Analisis Makna Leksikal pada lirik lagu diatas.}

\section{a. Repitisi (Perubahan)}

Repitisi adalah pengulangan pada satuan lingual (bunyi, suku kata, maupun bagian kalimat) yang dianggap penting untuk memberi tekanan dalam sebuah konteks yang sesuai pada lirik lagu "Kamu dan kenangan" terdapat repitisi (pengulangan) berupa repitisi Epizeukis adalah pengulangan satuan lingual yang dipentingkan beberapa kali secara berturutturut. Pada lairik lagu "Kamu dan kenangan" ditemukan beberapa repitisi yaitu :

(4) Tak Kuucapkan Aku mencintaimu setuja kali sehari.

(7) Kini Aku Kesepian

(10) Dan Aku kini sendirian

(14) Cintaku tak mungkin beralih

(15) sampai mata hanya cinta padamu

(15) Padamu

Pada lirik lagu diatas terdapat repitisi Epizeukis yang terdapat pada kata “Aku” pada data (4), (7), (10). Sementara Kata Kesepian diganti pada data (7), dan (10). Kata cinta diulang pada data (14),
(15) dan (32). Kata $m u$ dulang pada data (4), (15), dan (15).

\section{b. sinonimi (Persamaan kata)}

Sinonim merupakan salah satu aspek leksikal yang mendukung kepaduan wacana. Sinonimi berfungsi sebagai penjalin hubungan makna yang sepadan antara satuan lingual tententu dengan satuan lingual lain dalam wacana. Terdapat kutipan dari isi yang memiliki arti persamann yang terdapat pada lirik lagu "Kamu dan kenangan" antara lain :

\section{(13) Daripada kehilangan dirimu}

(2) Kepergianmu menyisakan duka dalam hidupku

Pada lirik lagu "Kamu dan kenangan" terdapat sinonim yang memiliki persamaan kata antara kata Kehilangan pada data (13) memiliki makna yang serupa dengan kata kepergian pada lirik lagu tersebut (2) sementara pada lirik laru kedua memiliki persamaan kata juga sehingga dari kedua makna kata tersebut sama-sama memiliki kesamaan dalam isi makna nya tersebut.

(8) Kamu segala kenangan

(11) menatap dirimu hanya bayangan

Yang selanjutnya, terdapat dilirik lagu ke (8) kata yang didalamnya terdaat 
kemiripan juga pada kata kenangan memiliki makna yang sama dengan lirik lagu dengan kata hanya bayangan yang terdapat pada data (11) jadi dapat disimpulkan bahwa makna yang terdapat dari kedua makna kata tersebut sama-sama terdapat arti yang sama namun hanya berbeda pada tulisan dari kata tersebut.

\section{c. Antonimi (Lawan kata)}

Antonimi atau lawan kata disebut juga dengan oposisi makna. Oposisi makna merupakan konsep yang betulbetul berlawanan sampai kepada yang hanya kontras makna saja. Berdasarkan sifatnya, oposisi dibedakan menjadi lima macam, yaitu oposisi mutlak, oposisi kutub, oposisi hubungan, oposisi hirarkial dan oposisi majemuk.

Dari hasil penelitian saya pada antonimi bahwasannya pada lirik lagu "Kamu dan kenangan" tidak ditemukan kata antonimi didalamnya. Sehingga saya memutuskan bahwa antonimi pada lirik lagu "Kamu dan kenangan" tidak ada.

\section{KESIMPULAN}

Berdasarkan hasil dan pembahasan diatas maka yang dapat peneliti simpulkan adalah makna leksikal dalam lirik lagu "Kamu dan kenangan" karya Maudy Ayunda adalah makna yang banyak ditemukan adalah Repitisi yang ditandai kata "padamu”, "cinta" dan "Aku” dan beberapa lirik yang mengalami pengulangan, lalu terdapat pula pada sinonimi (padan kata) yang ditandai kata “kehilangan”dan “ kepergian” serta kata “ kenangan" dan "bayangan".

\section{SARAN}

Dari hasil yang sudah diteliti maka penelitian ini dapat dijadikan sebagai bahan pembelajaran bahasa dan sastra Indonesia khususnya kepada mahasiswa yang ingin mengkaji makna laksikal pada lirik lagu, dengan ini kita dapat mendapatkan pemahaman baru terhadap aspek laksikal yang dihadirkan dalam lirik lagu khususnya pada penelitian kita terdapa lirik lagu "Kamu dan kenangan" yang ingin dikaji.

\section{DAFTAR PUSTAKA}

Arikunto, Suharsimi. 2010. Prosedur Penelitian. Jakarta: Rineka Cipta.

Chaer, Abdul. 2009. Pengantar Semantik Bahasa Indonesia. Jakarta: Rineka Cipta.

Mahsun. 2012. Metode Penelitian Bahasa Tahapan Strateg, Metode, dan Tekhniknya. Jakarta: PT Rajagrafindo Persada.

Oktafianus. 2006. Analisis Wacana Lintas Bahasa. Padang: Andalas University Press.

Pateda, Mansoer. 2010. Semantik Leksikal. Jakarta: Rineka Cipta. 